\title{
Economic Contributions and Environmental Effects of Geothermal Energy: Çanakkale-Tuzla Geothermal Example
}

\author{
Rüştü ILGAR* \\ Geography Education Department, Campus of Anafartalar, Çanakkale Onsekiz Mart University-Turkey \\ "Corresponding Author: Rüştü ILGAR, Geography Education Department, Campus of Anafartalar, \\ Çanakkale Onsekiz, Mart University-Turkey
}

\begin{abstract}
Today, energy is important, the value of renewable resource geothermal energy created by the economy is quite high. In addition, there are fewer environmental effects than fossil resources. Turkey has rich geothermal resources due to its location on the Alpine-Himalayan folds. Geothermal resources in Turkey are used in electricity generation, in industrial, agricultural, residential heating and health tourism. The Canakkale-Tuzla geothermal area, which is one of the geothermal areas in Turkey and located on the Biga Peninsula, is important due to the realization and privatization of electricity production from geothermal power. The research was carried out in order to examine the environmental effects and economic contributions of geothermal energy in Çanakkale-Tuzla. Çanakkale-Tuzla Geothermal Power Plant is Turkey's 776th with 7.50 MWe installed power and Çanakkale is the 16th largest geothermal power plant. The facility is also Turkey's 30th largest geothermal power plant. Tuzla Geothermal Power Plant has an average of 46,090,778 kilowatt hours of electricity production and can meet all the energy needs of 13,925 people in daily life. Annual electricity production of Tuzla Geothermal Power Plant is increasing continuously from 2012. According to 2015 data, this plant has achieved 1.04\% of the provincial production with 48.298.037 production. Similarly, according to 2015 data, Tuzla Geothermal Power Plant has received $0,018 \%$ of the total electricity generation in the country.
\end{abstract}

Keywords: Energy, Geothermal, Geothermal Energy, Çanakkale-Tuzla Geothermal Area.

\section{INTRODUCTION}

There is no doubt that one of the most important tools of human life and economic development is energy. This can be produced both from fossil fuels and from renewable sources. Approximately 39\% of the fuel usage of the countries is from petrol, $27 \%$ of them from coal, $21 \%$ of them from natural gas and $13 \%$ of them from hydroelectric and renewable energy sources (Pamir, 2003). For social and economic development, energy is among the most important means. In the 1970s, oil crises in the world had been a problem for countries that do not have rich oil reservoirs. The countries that often experience this problem are trying to balance their energy needs while reviewing their energy strategies. At the same time, these countries are gravitating towards renewable, sustainable, domestic, clean and new energy sources. Since the fossil resources are going to end sometime later, new energy sources will take their place. Hence, energy management is becoming more important each passing day. $87 \%$ of the total energy used in the world is based on fossil energy sources. Energy experts state that oil reservoirs can be used for about 40 years and natural gas reservoirs for 62 years (Pamir, 2003).

Generally, geothermal sources are used for various purposes such as domestic heating, electric power production, greenhouse heating, street and land heating, hot water supply and urban heating, tropical cultivation, various industrial uses, airport runway heating, food sterilization and drying, swimming pool and physiotherapy, canning, lumbering and wood paving industry, paper, etc. (Dağdaş, 2004). Electric power production depending on the industry was first made in 1913 in Larderello, Italy. This practice was a mechanism depending on dry steam production from the opened geothermal wells. In 1958 in Wairakei, New Zealand, electric energy was generated by a system developed from geothermal with flash technology. From this date to the present day, and with the oil crisis in 1973, energy production in the world has increased rapidly (World Energy Council, 1992). Reducing the greenhouse gases that are left in the atmosphere and reducing the danger of global warming is one of the great inspirations of today's people. Using fossil resources in energy production means global 
warming, climate change, floods, drought, rise in ocean or sea level, extreme weather conditions and deforestation. One of the ways to minimize these problems is to reduce fossil source usage to the minimum level and to use renewable, sustainable, clean, environmental-friendly energy fuels. In this regard, geothermal energy in many regions of the world can play an important role (Fridleifsson, 2007; Ragnarsson, 2010).

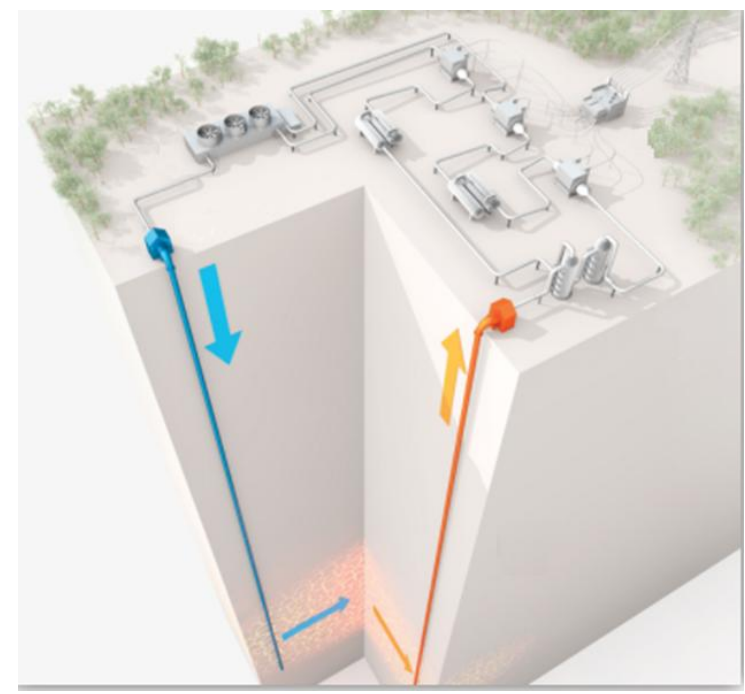

Figure1. Geothermal System (anonymous)

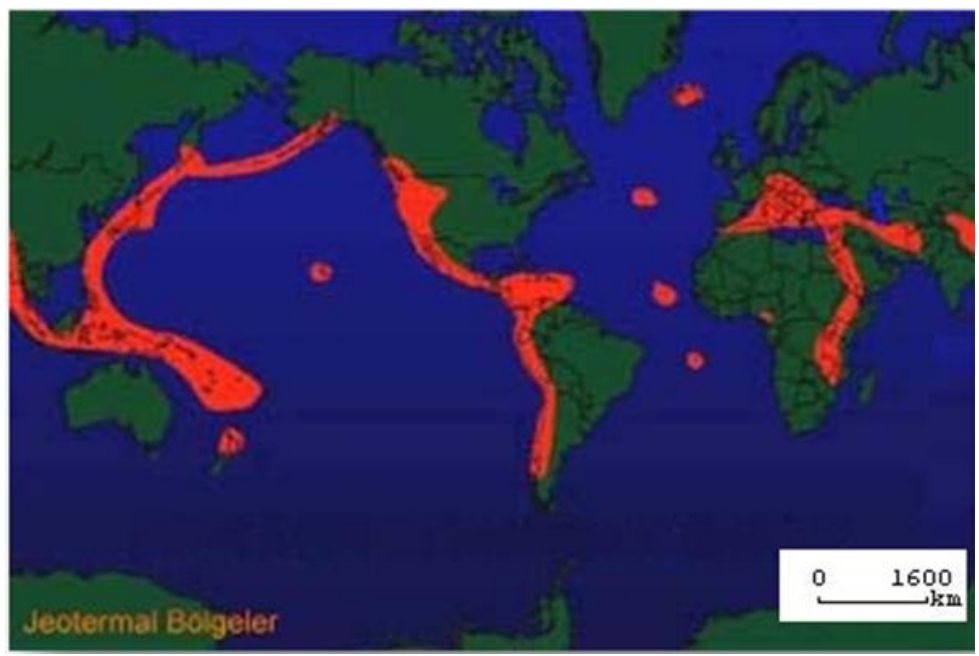

Figure2. Map of Plates and Volcanic Areas in the World (Ilgar, 2005)

Turkey ranks as seventh in the world and first in Europe in terms of geothermal energy with installed capacity of 31,500 MWt (Dağdaş, 2004). The following table lists the top 10 countries with the highest installed power generation capacity by geothermal energy source (Table 1).

Table1. Top 10 Countries with the Most Installed Energy Production Power by Geothermal Source

\begin{tabular}{|l|l|l|}
\hline & \multicolumn{1}{|c|}{ Country } & \\
\hline $1-$ & USA Powerful Open Power \\
\hline $2-$ & Philippines & 3450 \\
\hline $3-$ & Indonesia & 1870 \\
\hline $4-$ & Mexican & 1340 \\
\hline $5-$ & New Zeland & 1017 \\
\hline $6-$ & Italy & 1005 \\
\hline $7-$ & TURKEY & 916 \\
\hline $8-$ & Iceland & 725 \\
\hline $9-$ & Kenya & 665 \\
\hline $10-$ & Japan & 594 \\
\hline
\end{tabular}

(World Energy Council Turkish National Committee, 2010)

International Journal of Research in Geography (IJRG) 
Starting from 2008, the ongoing economic crises in the world have affected all countries more or less in terms of economic and social care. Depending on the crises, the demand for fossil resources such as petroleum, coal and natural gas in the world countries has decreased, but prices have increased. For this reason, European Union countries aimed at achieving their electricity needs from renewable and sustainable sources until 2020 (https://www.worldenergy.org).

\subsection{Turkey's Geothermal Situation}

As Turkey is in the Alpine-Himalayan belt, there are about 1500 hot and mineral springs with active faults due to young tectonics, hydro-thermal weathering zones and volcanoes. All of these is indicative of a significant potential for geothermal energy in Turkey. Graben zones, hydrothermal alteration, natural vapor and gas exits, widespread volcanism as a result of young tectonic movements show that Turkey has a significant presence in terms of geothermal energy (Kocak, 2000).

In the drillings made by MTA's General Directorate, the visible geothermal energy presence is 3158 MWt and the energy presence with these sources is 31,500 MWt (Seroskay and Lightning, 2007). Volume heating with the geothermal liquid of $40-45{ }^{\circ} \mathrm{C}$ is done in Turkey. The temperature of the geothermal fluids above $40^{\circ} \mathrm{C}$ has been observed in terms of volume heating and the water around 40 ${ }^{\circ} \mathrm{C}$ has been evaluated separately for the purpose of health (spa) (President, 1993; Hepbasli and Canakci, 2003). The value in 2017 shows the total geothermal electricity production in 2017, which is 2.000.189.400 kWh between 1 January and 26.05.2017.

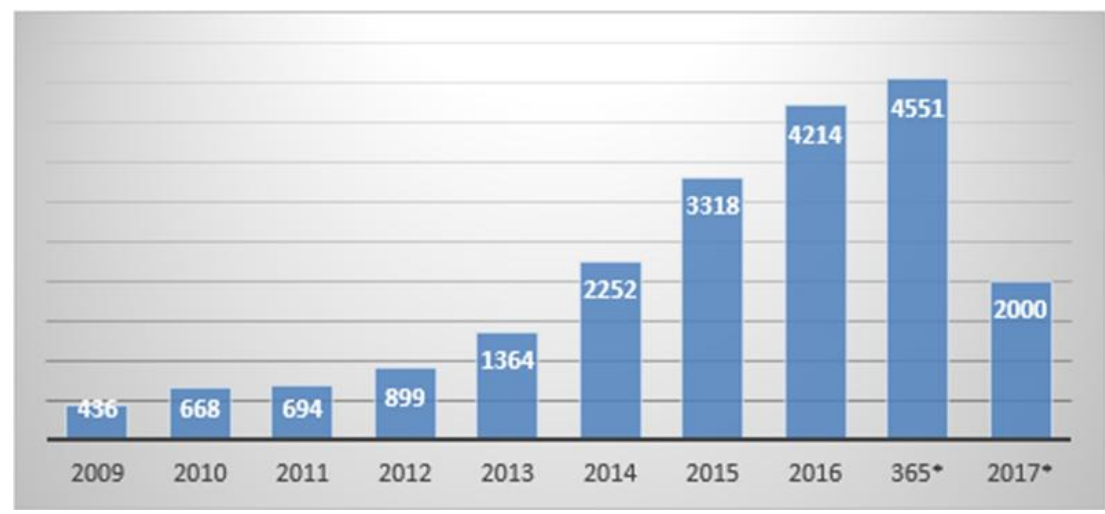

Figure3. Annual Power Generation of Geothermal Power Plants (Gwh)

(http://www.enerjiatlasi.com/elektrik-uretimi/jeotermal)

The ratio of power generation to total electricity consumption by geothermal energy during 20092017 is given in the graphic below.

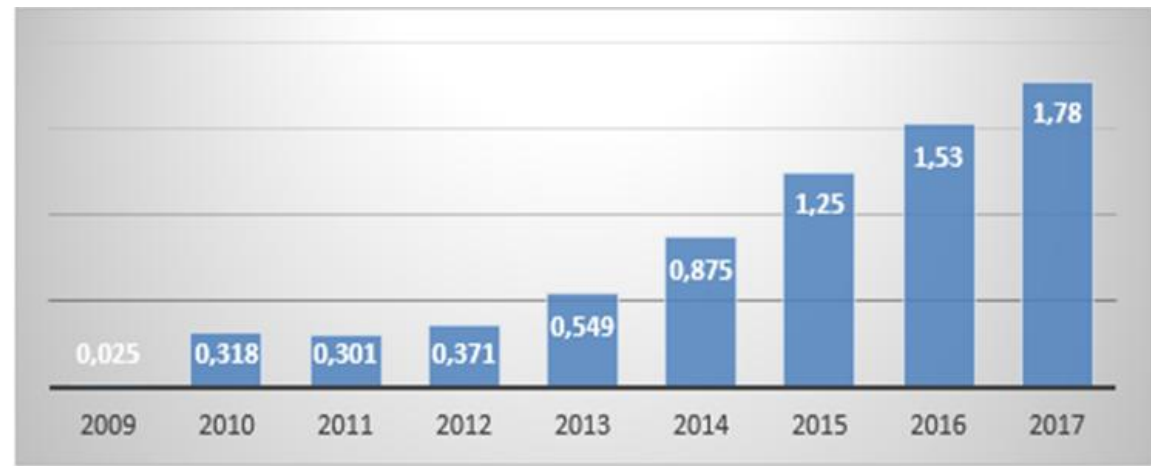

Figure4. Absorption Rate of Geothermal Power Plants Consumption (\%),

(http://www.enerjiatlasi.com/elektrik-uretimi/jeotermal):

\section{Materials AND Methods}

The main material of the study is the geothermal source in Çanakkale-Tuzla. For this, firstly, the concept of energy is referred and then renewable energy sources are examined. On the other hand, information about geothermal energy, which is one of the renewable energy fuels, is given; its importance is mentioned in terms of environmental, sustainable and renewable energy politics. 
In this study, which is a compilation study, the sources were examined by using the data scanning technique, in the result of these examinations, a deductive method that follows the theoretical concepts and different data contributed to the study, has been generally followed.

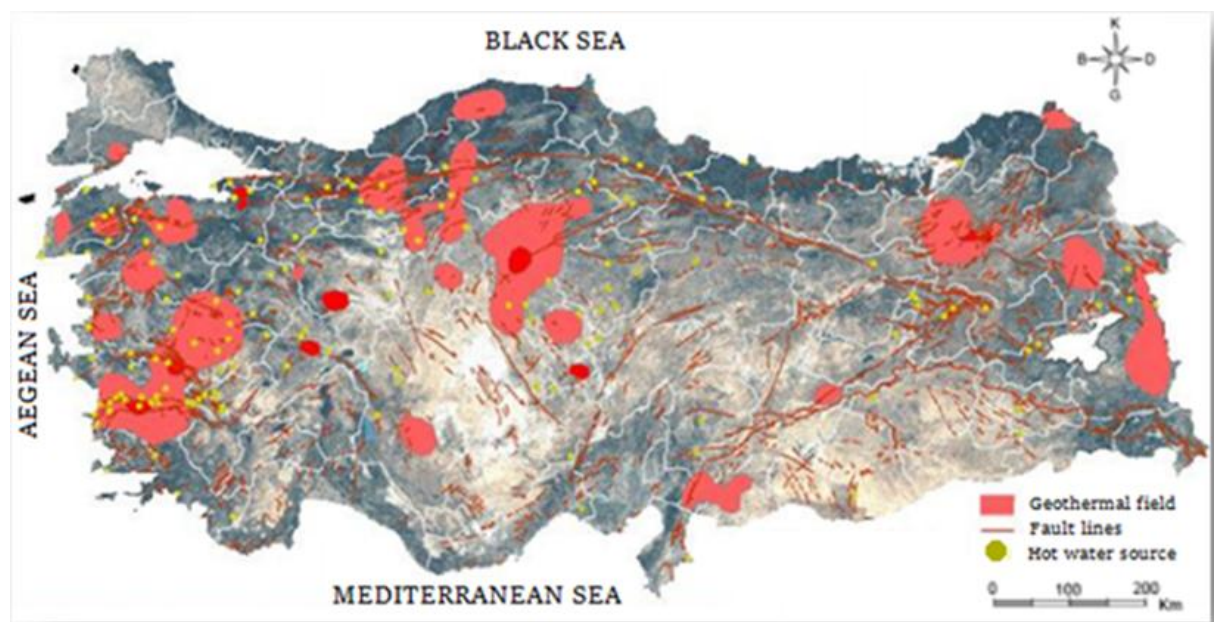

Figure5. Turkey Geothermal Sources and Application Map

http://www.mta.gov.tr/v1.0/daire_baskanliklari/enerji/index.php?id=haritalar

\section{3. ÇANAKKale-TuZla Geothermal Zone}

The geothermal field, which is the study area, is in the Ayvacık district of Çanakkale, the western border of the Edremit Gulf is Assos (Behramkale) and the eastern border is the settlement area of Kayalar. The researches carried out by the MTA in the geothermal field, the reports of the different universities and the examination of the fault zones of the area revealed that there is a structure with the same characteristics at the ahead of the Çanakkale Tuzla geothermal field . Coordinates of the site were determined after the works. It has been understood that a temperature value of $170-250{ }^{\circ} \mathrm{C}$ can be found in the research.

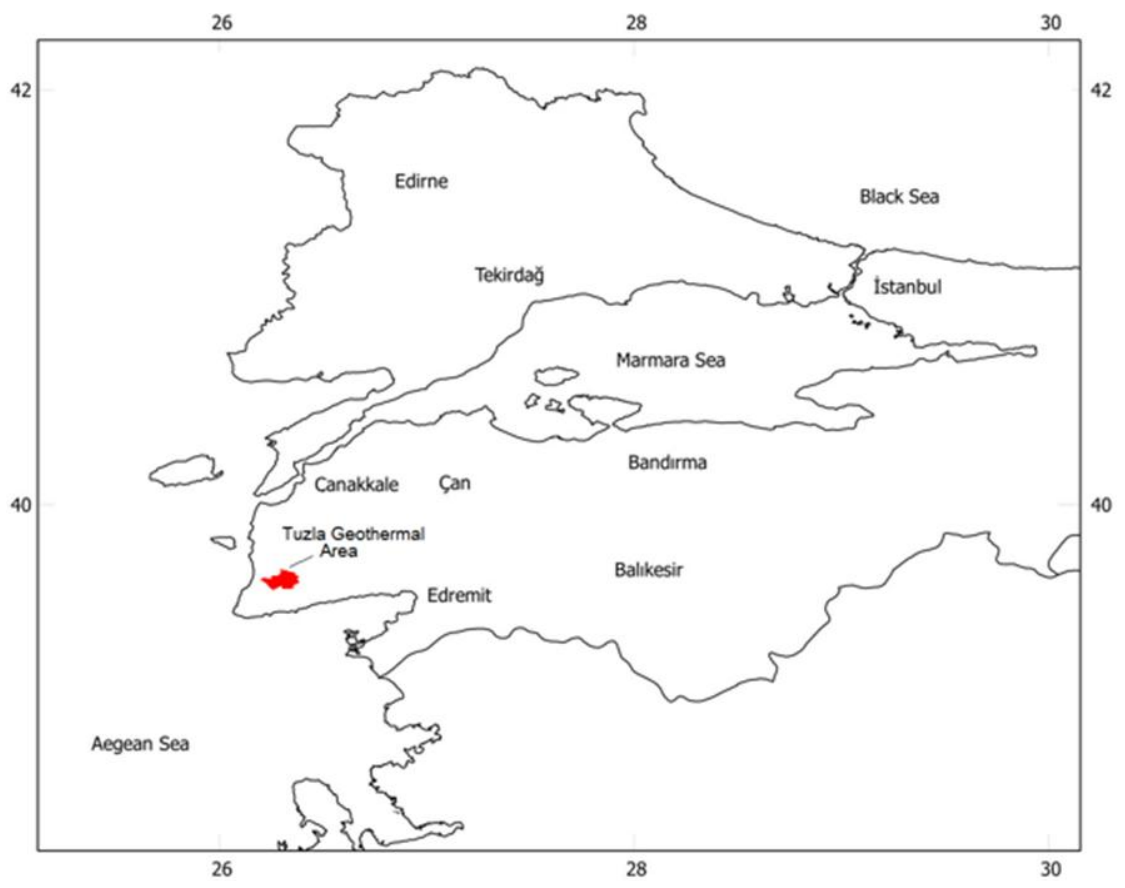

Figure6. Çanakkale-Tuzla Geothermal Zone

The foundation of the study area is metamorphic rocks. At the bottom, there are calcschist, quartzite and biotite gneisses. Above them dolomitic, crystallized limestones and marble are seen unconformable. All these metamorphic units are probable Palaeozoic aged and have smooth schistosity. Then there is a granodioritic pluton that cuts through these units. When Bürküt's (1966) modal analysis results of the rock, named as "Tuzla (Kestanbol) Pluto" by researchers (Ercan and 
Türkecan, 1984; Gözler et al., 1984) has been used in the triangular diagram of QAP Streckeisen (1976), it has been seen in monzogranite, granodiorite and quartz monzonite areas (Çanakkale, 2009). It is found in volcanic materials from all three volcanic areas, and it is difficult to distinguish them from each other in some areas (Innocenti et al., 1977); (Şener and Gevrek 2000). Throughout the Neogene, it was determined that the sea was undergoing a level change several times, and that the area underwent transgression and regression several times (Erinç et al., 1985).

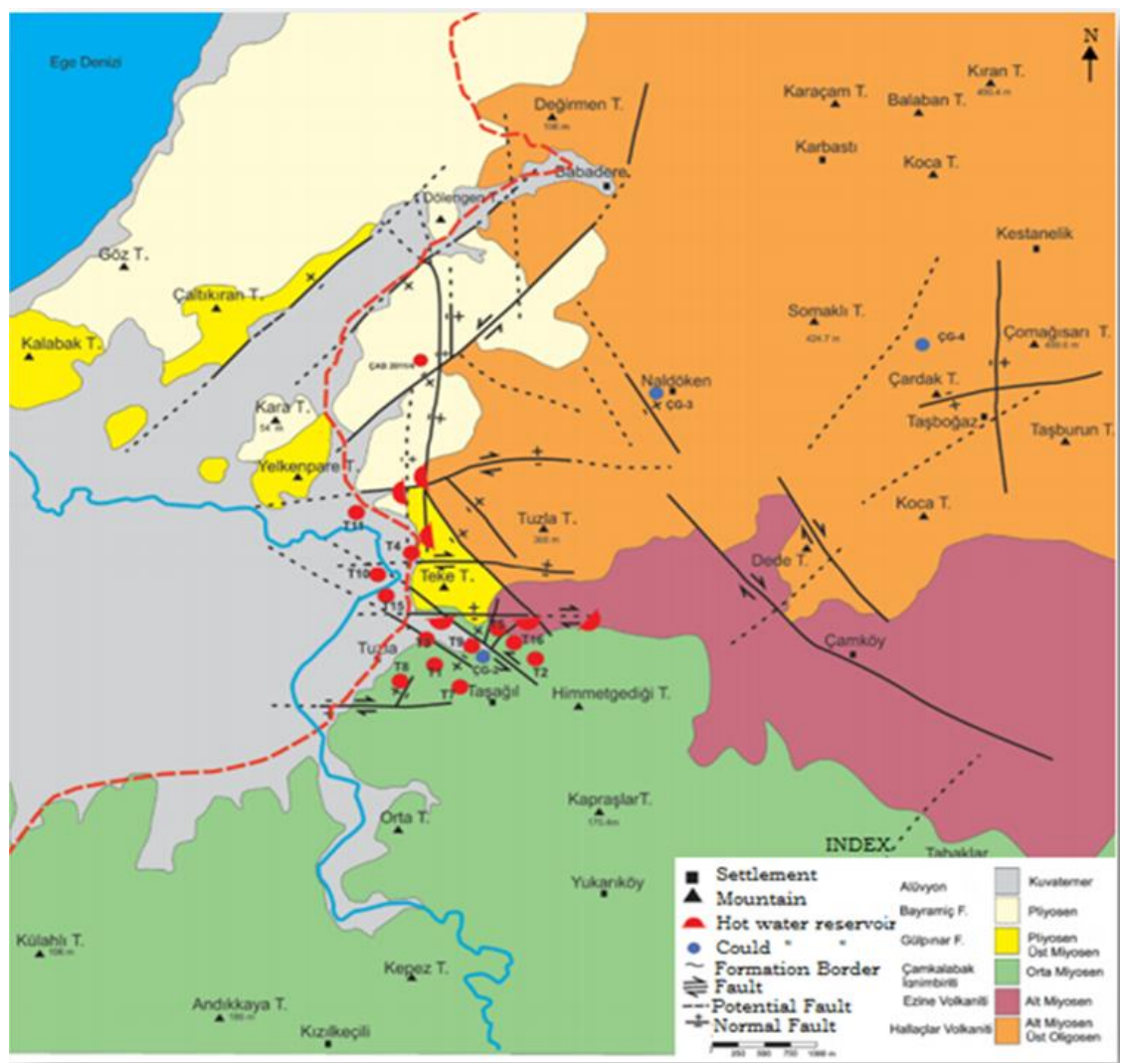

Figure7. Geological Map of the Study Site

(Çam et al., 2013)

Geothermal site was found in Denizli-Kizldere $\left(242^{\circ} \mathrm{C}\right)$ in 1968 during the studies carried out with the United Nations Development Organization (UNDP). In the following periods, Çanakkale-Tuzla $\left(174^{\circ} \mathrm{C}\right)$, Aydın-Germencik $\left(232^{\circ} \mathrm{C}\right)$, Aydın-Salavatl $1\left(171^{\circ} \mathrm{C}\right)$, Manisa-Salihli-Göbekli $\left(182^{\circ} \mathrm{C}\right)$, İzmir-Seferihisar $\left(153^{\circ} \mathrm{C}\right)$, Kütahya-Simav $\left(162^{\circ} \mathrm{C}\right)$ and İzmir-Dikili $\left(130^{\circ} \mathrm{C}\right)$ have been discovered.

Table2. Suitable sites for power generation

\begin{tabular}{|l|l|}
\hline \multicolumn{2}{|c|}{ Suitable Sites For Electricity Generation in Turkey } \\
\hline $1-$ & Denizli-Kızldere $\left(242^{\circ} \mathrm{C}\right)$ \\
\hline $2-$ & Aydın-Germencik $\left(232^{\circ} \mathrm{C}\right)$ \\
\hline $3-$ & Manisa-Alaşehir-Kurudere $\left(184^{\circ} \mathrm{C}\right)$ \\
\hline $4-$ & Manisa-Salihli-Göbekli $\left(182^{\circ} \mathrm{C}\right)$ \\
\hline $5-$ & Çanakkale-Tuzla $\left(174^{\circ} \mathrm{C}\right)$ \\
\hline $6-$ & Aydın-Salavatl $\left(171^{\circ} \mathrm{C}\right)$ \\
\hline $7-$ & Kütahya-Simav $\left(162^{\circ} \mathrm{C}\right)$ \\
\hline $8-$ & İzmir-Seferihisar $\left(153^{\circ} \mathrm{C}\right)$ \\
\hline $9-$ & Manisa-Salihli-Caferbey $\left(150^{\circ} \mathrm{C}\right)$ \\
\hline $10-$ & Aydın-Yılmazköy $\left(142^{\circ} \mathrm{C}\right)$ \\
\hline $11-$ & İzmir-Balçova $\left(136^{\circ} \mathrm{C}\right)$ \\
\hline $12-$ & İzmir-Dikili $\left(130^{\circ} \mathrm{C}\right)$ \\
\hline
\end{tabular}

(Yeksem, 2009)

Turkey has, instead of fossil fuels that cause an increase in the greenhouse effect, clean energy sources such as geothermal. Tuzla Geothermal Power Plant is located in Tuzla region of Ayvacik 
district of Çanakkale province. It belongs to Santral Enda Energy Company. This plant, with its installed capacity of $7.50 \mathrm{MWe}$, is the 16th largest power plant of Çanakkale, and the 776th of Turkey. Moreover, the plant is 30th largest geothermal power plant of Turkey. With an average of 46.090.778 kilowatt-hours of electricity generation, the Tuzla Geothermal Power Plant can meet all the electricity needs of 13.925 people in their everyday life (government agency, environmental luminance, industry, dwelling, etc.). When only the electricity consumption of the dwelling is taken into consideration, Tuzla Geothermal Power Plant produces electricity at a level that can meet the electricity needs of 14,632 dwellings.

Table3. Tuzla Geothermal Power Plant Details

\begin{tabular}{|l|l|}
\hline \multicolumn{2}{|c|}{ Tuzla Geothermal Power Plant } \\
\hline Installed Power & $7,50 \mathrm{MWe}$ \\
\hline Board Ratio & $\% 0.0095$ \\
\hline Production capacity & $63 \mathrm{GWh}-\mathrm{yll}$ \\
\hline Annual Electricity Generation & $\sim 46 \mathrm{GWh}$ \\
\hline 2015 Production & $48 \mathrm{GWh}$ \\
\hline Power Plant Location & Çanakkale, Ayvacık \\
\hline Operator Company & Enda Enerji \\
\hline License No & EÜ/318-12/451 \\
\hline
\end{tabular}

http://www.enerjiatlasi.com/jeotermal/tuzla-jeotermal-enerji-santrali.html

In 2016, Tuzla Geothermal Power Plant benefited from the Renewable Energy Sources Support Mechanism (YEKDEM) and sold 1-kilowatt hour of electricity to the state with a fee of $\$ 0.1050$. Tuzla Geothermal Power Plant-JES YEKDEM establishment will benefit until 2020.

The annual electricity production details of the Tuzla Geothermal Power Plant can be summarized as follows:

Table4. Electricity Generation by Years in Tuzla Geothermal Power Plant and Ratio of this Production to Province and Country Consumption

\begin{tabular}{|l|l|l|l|}
\hline \multicolumn{1}{|c|}{ Year } & Production $(\mathbf{k W h})$ & Rate of Provincial Consumption & Rate of Country Consumption \\
\hline 2012 & 32.918 .000 & $\% 0,77$ & $\% 0,014$ \\
\hline 2013 & 42.812 .353 & $\% 0,99$ & $\% 0,017$ \\
\hline 2014 & 43.425 .498 & $\% 0,97$ & $\% 0,017$ \\
\hline 2015 & 48.298 .037 & $\% 1,04$ & $\% 0,018$ \\
\hline
\end{tabular}

(http://www.enerjiatlasi.com/jeotermal/tuzla-jeotermal-enerji-santrali.html)

Tuzla Geothermal Energy Incorporated Company was established in Enda Energy in Tuzla, village of Ayvacik. Since 2010, this plant has been generating electricity from geothermal energy and has a production capacity of $6.5 \mathrm{MW}$ per hour. The annual electricity generation of the power plant is constantly increasing from 2012. According to 2015 data, this plant supplied $1.04 \%$ of total provincial electricity consumption with 48.298 .037 production. Similarly, according to 2015 data, Tuzla Geothermal Power Plant has supplied $0.018 \%$ of total country electricity consumption.

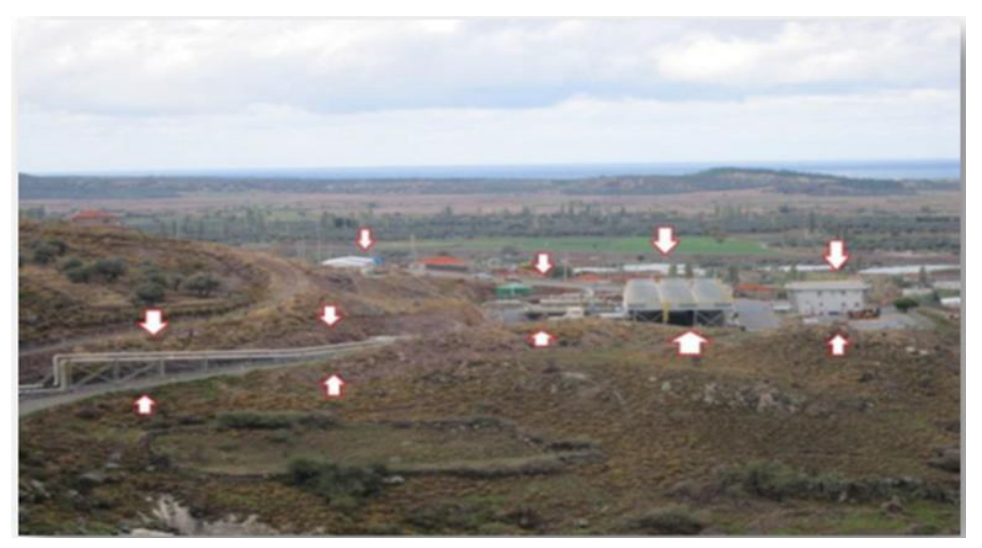

Figure8. Çanakkale-Tuzla Geothermal Energy Site

(Çanakkale, 2009) 
Some companies are continuing their drilling activities in the region except for one private company (Enda Energy) mentioned above. In Tuzla Geothermal Zone, there are hot springs for tourism and health as well as geothermal system. There are also mineral-based geothermal sources.

\section{CONCLUSION AND RECOMMENDATIONS}

Depending on the GDP growth and the growth of Turkey's population, energy demand is growing rapidly. For this reason, Turkey should pass to a new, renewable, sustainable, environmentally friendly and domestic energy sources from approximately $73 \%$ foreign-dependent energy politics based on fossil sources. Geothermal system model is related to geological formation. Turkey is a rich country in terms of geothermal energy sources, but cannot benefit from these sources at the satisfactory level. Yet with the privatization activities, there has been a rapid rise in recent times.

Tuzla has a rich presence in terms of underground and over ground sources due to its geographical structure (Baba et al., 2008). Çanakkale-Tuzla Geothermal Power Plant, with its installed capacity of 7.50 MWe, is the 16th largest power plant of Çanakkale, and 776th of Turkey. In addition, the plant is the 30th largest geothermal power plant of Turkey. Tuzla Geothermal Power Plant can meet all the electricity needs of 13.925 people in their everyday life with an average of 46.090 .778 kilowatt-hours of electricity generation. However, the study of the effects on the land, which can be caused by excessive water withdrawal, is a necessary matter.

It is a region where long-term investments can be made, where renewable energy sources can be efficiently utilized and where there are efficient sources. Some of the waters in the depths of this region contain condensed gases such as hydrogen sulphide (H2S) and carbon dioxide (CO2) and minerals such as zinc. In the geothermal power plants in Tuzla, such pollutants must be destroyed or processed.

Precautions should be taken for this; wastes should not be thrown into the environment. In order to achieve this, the waste should be reprocessed by re-injection if necessary. In this manner, nature can be protected in an effective manner (Erkul, 2012). In other words, geothermal reservoirs that feed the cracked and porous rocks under the sea, snow, rain and magmatic waters, continue to maintain sustainable and renewable structures as long as underground and re-injection (repressing) conditions continue.

\section{REFERENCES}

[1] Arslan E. 2006. Jeotermal Enerjiden Yararlanılarak Kuyu İçi Eşanjörü Yardımıyla Konut Isıtılması ve Sicak Su İhtiyacının Karşılanması, Pamukkale Üniversitesi Fen Bilimleri Enstitüsü, Yüksek Lisans Tezi, Denizli.

[2] Baba A., Ateş Ö., Deniz O., 2008. The Environmental And Hydrogeochemical Properties Of The Tuzla Kestanbol - Hidırlar Geothermal Sources, Turkey, 30th Anniversary Workshop, August 26-27, 2008, United Nations University, Iceland.

[3] Başkir H. 1993. Türkiye' De Jeotermal Enerjinin Isıtma Amaçlı Kullanım Potansiyeli ve Afyon Şehrinin Hava Kirliliğinin Azaltılmasında Jeotermal Enerjiden Yararlanma İmkanları, Yıldız Teknik Üniversitesi Fen Bilimleri Enstitüsü, Yüksek Lisans Tezi, İstanbul.

[4] Bürküt Y., 1966. Kuzeybatı Anadolu'da Yer Alan Plutonlarin Mukayeseli Jenetik Etüdü: Doktora Tezi, İTÜ Maden Faculty, İstanbul, $272 \mathrm{p}$

[5] Çam D, Bülbül E, Kılınç O, Şan Ö. 2013. Jeotermal Akışkanların Köken İlişkisi: Tuzla ve Babadere (Çanakkale) Sahaları Örneği. Ekonomi Bültenleri (15):79-87 p.

[6] Çanakkale Geothermal Zone Summary Feasibility Report_23/37, 2009

[7] Dağdaş A. 2004. Jeotermal Enerjiden Yararlanmada Türkiye'nin Dünyadaki Konumu ve Potansiyeli, http://www.mmoistanbul.org (Access Time: 23.05.2012).

[8] Ercan T. and Türkecan A., 1984. Bati Anadolu, Ege Adalari, Yunanistan ve Bulgaristan'daki Plutonlarin Gözden Geçirilisi: TJK Ketin Sempozyumu Kitabi, 189-208p.

[9] Erinç S., Kurter A., Eroskay O., Mater B. 1985. Batı Anadolu ve Trakya Uygulamalı Jeomorfoloji Haritası 1/500.000. TÜBİTAK TBAG Proje No. 593, Ankara.

[10] Erkul H., 2012. Jeotermal Enerjinin Ekonomik Katkıları ve Çevresel Etkileri: Denizli-Kızıldere Jeotermal Örneği, Yönetim. Bilimleri Dergisi, Cilt: 10, Sayı: 19,1-30 p.

[11] Fridleifsson I. B., 2007. Geothermal energy and the Millennium Development Goals of the United Nations. Proceedings of the European Geothermal Congress 2007, Unterhaching, Germany 
[12] Gevrek İ., Şener M., Ercan T. 1985. 'Çanakkale-Tuzla Jeotermal Alanının Hidrotermal Alterasyon Etüdü ve Volkanik Kayaçların Petrolojisi', http://www.mta.gov.tr/v2.0/daire baskanliklari/bdt/kutuphane/ mtadergi/103-104_4.pdf

[13] Gözler M.Z., Ergil E., Akaren F., Gen. İ.C., Akat A. İ. 1984. Geology of the Area of East of DardanellesSouth of Sea of Marmara-Bandırma-Edremit and Agean Sea, Maden Tetkik ve Arama Enst Report No. 7430

[14] Hepbaşli A., Çanakçi C. 2003. Geothermal District Heating Applications in Turkey: A Case Study Of İzmir-Balçova, Energy Conversion and Management, 44; 1285-1301 p.

[15] Ilgar R. 2005. Ekolojik Bakışla Jeotermal Kaynaklara Dualist Yaklaşım, Elektronik Sosyal Bilimler Dergisi, Cilt 4, Say1 13,88-98 p.

[16] Innocenti F., Kolios N., Manetti P., Rita F., Villari L., 1982. Acid and Basic Late Neogene Volcanism in Central Aegean Sea; Its Nature and Geotectonic Significance: Bull. Volcan., 45/2, 87-97p.

[17] Şimşek Ş. Eroskay, O. 2007. "Küresel Isınmaya Karşı Türkiye'de Jeotermal Enerji Olanağı”, Cumhuriyet Gazetesi Eki CBT, Sayı: 1056

[18] Koçak A., 2000. Türkiye'de Jeotermal Enerji Armaları ve Potansiyeli, Türkiye 8. Enerji Kongresi, Cilt 2, 109-124 p., Ankara

[19] Pamir, N. 2003. Dünyada ve Türkiye'de Enerji, Türkiye'nin Enerji Kaynakları ve Enerji Politikaları, Metalurji Dergisi, Sayı: 17 (134), 73-100 p.

[20] Ragnarsson A., 2010. Geothermal Development in Iceland 2005-2009, Proceedings of the World Geothermal Congress 2010, Bali, Indonesia, p.12

[21] Streckeisen A. 1976. Classification of Common Igneous Rocks by Mean of Their Chemical Composition. A Provisional Attempt. Neues Jahrbuch für Mineralogie, Monatshefte, 1, 1-15 p.

[22] Sener M., Gevrek A., 2000. Distribution and Significance of Hydrothermal Alteration Minerals in The Tuzla Hydrothermal System, Canakkale, Turkey. J. Volcanol.Geotherm. Res. 96, 215-218 p.

[23] Yeksem 2009. V.Yenilebilir Enerji Kaynakları. Sempozyumu, Bildiriler Kitab1 19-20-21 Haziran 2009Diyarbakır, EMO Yayın No: SK/2009/7

[24] https://www.worldenergy.org/wp-content/uploads/2013/09/Complete_WER_2013_Survey.pdf (Access Time: 13.08.2017).

[25] http://www.enerjiatlasi.com/elektrik-uretimi/jeotermal (Access Time: 17.08.201).

[26] http://www.enerjiatlasi.com/jeotermal/tuzla-jeotermal-enerji-santrali.html (Access Time: 17.08.201).

[27] http://www.mta.gov.tr/v1.0/daire_baskanliklari/enerji/index.php?id=haritalar (Access Time: 17.08.201).

Citation: Rüştü ILGAR. "Economic Contributions and Environmental Effects of Geothermal Energy: Çanakkale-Tuzla Geothermal Example”. International Journal of Research in Geography. vol 5, no. 1, 2019, pp. 1-8. doi: http://dx.doi.org/10.20431/2454-8685.0501001.

Copyright: (c) 2019 Authors. This is an open-access article distributed under the terms of the Creative Commons Attribution License, which permits unrestricted use, distribution, and reproduction in any medium, provided the original author and source are credited. 